\title{
Reference Books of 1977-78: A Selection
}

This is the fifth annual listing of reference books selected by librarians of the Slavic and East European Division of the University of Illinois Library at UrbanaChampaign. Annotations are signed with the initials of the reviewers. ${ }^{1}$ Library of Congress entries have been used and available Library of Congress card numbers have been added to facilitate access to the books by scholars and librarians.

\section{General}

European Bibliography of Soviet, East European and Slavonic Studies. Vol. 1: 1975. Edited by Thomas Hnik. Birmingham, England: University of Birmingham, 1977. xxxvii, 437 pp. $\$ 12.00$. Two former bibliographies, Soviet, East European and Slavonic Studies in Britain (published by ABSEES) and Travaux et publications parus en français en . . . sur la Russie et l'URSS (published in Cahiers du monde russe et sovićtique), are combined in this annual listing of books, articles, and scholarly reviews published in Western Europe. The British and French lists are augmented by the inclusion of German and Austrian publications. Subject coverage spans the humanities and social sciences. The 3,961 citations in the first volume are classified according to the system formerly employed in the French listing. Use of the bibliography is facilitated by a combined author-subject index of personal names. $-\mathrm{MS}$.

Horak, Stephan M. Russia, the USSR, and Eastern Europe: $A$ Bibliographic Guide to English Language Publications, 1964-1974. Edited by Rosemary Neiswender. Littleton, Colo.: Librar-

1. Robert Burger, Marianna Tax Choldin, Harold Leich, Laurence H. Miller, June E. Pachuta, Dmytro M. Shtohryn, Mary Stuart. ies Unlimited, 1978. 488 pp. $\$ 25.00$. LC 77-20696.

This volume is intended to update Paul Horecky's Russia and the Soviet Union: $A$ Bibliographic Guide to Western Publications (1965) and his volumes on East Central and Southeastern Europe (1969). The 1,611 entries are annotated with excerpts from or adaptations of reviews in British and American journals devoted to Slavic studies. Where no review could be found, annotations have been supplied by the compiler. Included in the three parts of the book are general works, works on Russia and the Soviet Union, and works on Eastern Europe (including the Balkans). Only monographic publications are listed. Author-title and subject indexes are appended.-MTC.

Shaffer, Harry G. Periodicals on the Socialist Countries and on Marxism: $A$ New Annotated Index of English-Language Publications. Praeger Special Studies in International Politics and Government. New York: Praeger Publishers, 1977. xiii, 133 pp. $\$ 14.00$. LC 75-36907.

A revised and expanded edition of the author's 1971 English-Language Periodic Publications on Communism, the bibliography lists approximately 450 Englishlanguage serial publications in the social sciences and humanities which are wholly or primarily devoted to the Communist countries and to Marxism in general (Mongolia, North Korea, Cuba, and the Indochinese states are included along with the USSR and Eastern Europe). The list covers both translation journals and original English-language titles published in Russia, East Europe, and the West. Each title is accompanied by a detailed annotation and by publication and subscription information. There is a "geographic reference index," useful for those interested in only one or a few of the 
countries treated, and a selected list of subscription agencies in the United States and dealers who handle subscriptions to journals from the socialist countries.HL.

\section{Bulgaria}

Rechnik na bülgarskiia ezik. Vol. 1: $A-B$. Kristalina Cholakova, chief editor. Sofia: Izdatelstvo na Bŭlgarskata Akademiia na naukite, 1977.910 pp. 7.36 lv. LC 78-420588.

This is the first volume of a projected fifteen-volume Bulgarian dictionary, prepared at the Bulgarian Language Institute of the Bulgarian Academy of Sciences. The goal of the set is to record the entire lexical stock of modern Bulgarian from approximately the first quarter of the nineteenth century to the present. In addition to the current standard literary language, the dictionary includes archaic and obsolete words, Church Slavonicisms, and foreign, technical, and dialectal terms found in written Bulgarian. The first volume contains several lengthy introductory articles setting forth the history, scope, methodology, and use of the dictionary and includes citations to about 2,500 Bulgarian works from which illustrative examples of entries in the dictionary were taken.-HL.

\section{Czechoslovakia}

Encyklopédia Slovenska. Vol. 1: $A-D$. Edited by Vladimír Hajko et al. Bratislava: Veda, 1977. 617 pp. Kčs. 150. LC 78-388176.

This is the first of a projected sixvolume work which will have more than sixteen thousand entries, most of which relate specifically to Slovakia and Czechoslovakia as a whole, with emphasis on post-1948 developments. All areas of the arts and sciences are covered, with numerous entries for current figures in Slovak government, education, arts, and so forth. Also included are entries for government agencies, scholarly institutions, trade unions, congresses, factories, museums, and others. The first volume contains over two thousand illustrations, many in color.-JEP.

\section{Poland}

Stanisławski, Jan. Wielki siownik polskoangielski z suplementem. 2 vols. Edited by Wiktor Jassem. Warsaw: Wiedza Powszechna, 1978. Vol. $1(A-\sigma): 800$ pp. Vol. $2(P-\dot{Z})$ : 928 pp. 600 zł. for 2 vols. LC 79-338334.

Now in its fourth edition, this Polish to English dictionary defines and illustrates some 180,000 words, phrases, and expressions. First published in 1969, it was designed to complement the author's Wielki slozenik angielsko-polski (1964). A supplemental section of new words and meanings has been added to the fourth edition. As in previous editions, the appendixes include lists of Polish geographical names and common abbreviations and an essay entitled "Elements of Polish Grammar" (in English and Polish) by Jan Tokarski of Warsaw University.MS.

\section{RUMANIA}

Rumänien. Edited by Klaus-Detlev Grothusen. Südosteuropa-Handbuch, vol. 2. Göttingen: Vandenhoeck \& Ruprecht, 1977. 711 pp. DM 175. LC 78-363627.

Eighteen detailed articles (three of which are in English) on Rumanian politics, government, economics, society and social structures, and culture and scholarship are included in the collection. Emphasis in all articles is on the post-1944 period. Appendixes supply a chronology of important events in Rumanian history from 1944 to 1977, a list of treaties and conventions between Rumania and other states, biographies of prominent Rumanian political leaders, and a classified bibliography (containing 1,300 items) of books and journal articles on Rumania. It is the second volume in a series of handbooks on contemporary Southeastern 
Europe prepared under the auspices of the Committee of Southeast European Studies of the German Science Foundation.-HL.

\section{Russia AND Soviet Union}

Andreeva, Nina Fedorovna. Russkaia periodicheskaia pechat': Obshchie $i$ otraslevye bibliograficheskie ukazateli, 1703-1975: Annotirovannyi ukazatel'. By N. F. Andreeva and M. V. Mashkova: Gosudarstvennaia publichnaia biblioteka imeni M. E. SaltykovaShchedrina. Moscow: "Kniga," 1977. 183 pp. 95 kopecks. LC 78-416406.

The basic guide to Russian periodicals bibliography by M. V. Mashkova and M. V. Sokurova, Obshchie bibliografii russkikh periodicheskikh izdanii, 17031954 (1956), has been superseded by this exemplary new work. In addition to the inclusion of many fundamental serial bibliographies published since 1954, regional and subject bibliographies and bibliographies of irregular serial publications broaden the scope of the present guide. Extensive annotations to 318 numbered citations contain references to additional bibliographies and to important reviews and criticism, all of which is made readily accessible by appropriate indexing. The authors are fully justified in observing that this work may be used not only as a guide to bibliographies, but also as a basic source for the study of Russian bibliography and the history of the Russian periodical press.-LHM.

Cooper, Henry R., Jr. The Igor Tale: $A n$ Annotated Bibliography of Twentieth Century Non-Soviet Scholarship on the "Slovo o polku Igoreve." Columbia Slavic Studies. White Plains, N. Y. and London: M. E. Sharpe and Mansell, 1978. vi, 130 pp. $\$ 20.00$. LC 77-85703. This work includes brief annotations describing 390 citations to the broad range of non-Soviet scholarship on the Slovo o polku Igoreve which has been published between 1900 and 1976. The bibliography is divided into six main sections: bibliographies, texts, translations, and commentaries, linguistic analyses, literary analyses, historical analyses, and reviews of Soviet scholarship. Roman Jakobson's fifth reconstruction of the Slovo is included in an appendix. Cooper provides a lucid and informative introduction to Slovo scholarship and two auxiliary indexes: a word and verse index, and title, author, coauthor, and reviewer index. The work should prove indispensable to anyone studying Old Russian literature.-RB.

Eimermacher, Karl. Subject Bibliography of Soviet Semiotics: The Moscow-Tar$t u$ School. By Karl Eimermacher and Serge Shishkoff. Michigan Slavic Publications. Bibliographic Series, 3. Ann Arbor: University of Michigan, Department of Slavic Languages and Literatures, 1977. xv, 153 pp. $\$ 4.50$. LC 77-624121.

Consisting of 2,138 numbered citations and cross references, Eimermacher and Shishkoff's bibliography is arranged in eight broad categories, some of which are broken down in more detail. The entries are transliterated using the international linguistic system. The bibliography includes an introduction that describes the development and program of the MoscowTartu School of Semiotics. Although one might assume comprehensiveness to within a year of the publication date, there is no statement about the chronological limits of the work. The inclusion in the author index of numbers for cross references may cause some frustration for the user.-RB.

\section{Istoriia SSSR: Ukazatel' soderzhaniia zhurnala 1957-1976. Compiled by N. Ia. Kraineva and P. V. Pronina. Akade- miia nauk SSSR, Institut istorii SSSR. Moscow: "Nauka," 1978. 158 pp. 1 ruble.}

All material published during the first twenty years of the journal Istoriia SSSR is indexed in Kraineva and Pronina's work. The citations included in this thorough and remarkably inexpensive index are arranged under broad subject categories in two main parts: "Istoricheskaia 
nauka" and "Istoriia SSSR." A citation to an article is listed only once, with a total of 3,731 given. Most subject divisions are cross referenced to other citations related to the subject at hand. The work has two auxiliary indexes: one of authors, compilers, reviewers, names, titles of books reviewed and titles of items lacking authors, and the other of geographical names. $-\mathrm{RB}$.

Izuchenie otechestvennoi istorii $v$ SSSR mezhdu XXIV i XXV s"ezdami KPSS. 2 vols. Edited by A. L. Narochnitskii et al. Akademiia nauk SSSR, Institut istorii SSSR. Moscow: "Nauka," 1978. 4.80 rubles. LC $78-421800$.

Indexes of personal names contained in both volumes make possible the use of this work for reference purposes. Twentyone bibliographic essays by leading Soviet historians on various periods and historical topics are included. The first volume covers the Soviet period and the second deals with the prerevolutionary period. The chronological coverage of historical writing (1971-75) is expanded in several of the surveys.-LHM.

Levin, Vladimir Lazarevich. Putevoditel dlia biologov po bibliograficheskim izdaniiam: Spravochnoe posobie. By V. L. Levin, V. G. Levina, and D. V. Lebedev. Leningrad: "Nauka," 1978. 480 pp. 2 rubles.

V. L. Levin's earlier guide to biologićal bibliography (Spravochnoe posobie po bibliografii dlia biologov [Moscow, 1960]) has been regarded as a model of the genre. The new volume maintains the high standard set in 1960. The compilers -who are biologists as well as bibliographers-have included both Russian and non-Russian material and present it in five main categories: (1) general tools for current literature, (2) tools for retrospective literature, (3) tools for the various fields within biology, (4) regional guides to literature on the USSR, and (5) supplementary sources. Entries are richly annotated. The alphabetical index includes authors of works described by title, periodical publications with indexes, and organizations.-MTC.
The Modern Encyclopedia of Russian and Soviet Literature. Vols. 1 and 2: $A b a-$ ginskii-Bible, Armenian. Edited by Harry B. Weber. Gulf Breeze, Fla.: Academic International Press, 1977-78. Vol. 1: 246 pp. \$30.50. Vol. 2: 246 pp. $\$ 30.50$. LC 77-78428.

This new work attempts comprehensive coverage and is meant to aid both the specialist in need of ready reference and the general reader. Entries are arranged using one alphabet, ranging from a few lines to signed articles of several pages, and include not only literary figures, movements, and so forth, but also selected linguistic and folklore terminology. Almost all articles are accompanied by bibliographies. The addition of many substantial articles on émigré authors and on writers no longer recognized by the Soviets-along with other original material - marks this work as more than a mere compilation of translations from Russian and Soviet works. In cases where entries consist of direct translations (sometimes perpetuating the Soviet practice of supplying Russian patronymics for non-Slavic writers), attempts were made to update the bibliographies. Original titles are usually given in the bibliographies, although some non-Slavic works are cited only in their Russian translations. Ukrainian authors and titles are often incorrectly transliterated as Russian (such as Dmitro Bedzik instead of Dmytro Bedzyk, Bagmut instead of Bahmut). The format is very straightforward and easy to use.-JEP.

Russkaja mysl' 1905-1918. Compiled by Werner Barlmeyer. Edited by Hans Rothe. Bausteine zur Geschichte der Literatur bei den Slawen: Bibliographie, vol. 10. Giessen: Wilhelm Schmitz Verlag, 1977. 374 pp. DM 65. LC 77-555604.

This index to Russkaia mysl' covers the part of the periodical that has never been indexed (1905-18). The years 18801904 have been treated in three separate indexes for the periods $1880-89,1890$ 99, and 1900-1904, all published prior to 1917. Barlmeyer's index is divided into 
two parts: a classified subject index and a personal name index. The subject index is the main listing and contains 4,267 entries by author, title, and citation. These entries are chronological within some forty subject sections. The personal name index to the citations includes authors, translators, reviewers, and subjects. There are occasional cross references to alternate forms of names.-RB.

\section{Ten Bibliographies of Twentieth Century} Russian Literature. Edited by Fred Moody. Ann Arbor: Ardis, 1977. 175 pp. $\$ 14.95$.

The subjects of the bibliographies listed in this book are Kuprin, Annenskii, Blok (The Twelve only), Evreinov, Mayakovsky (1912-30), Grin (1880-1932), Aksenov, Soviet publications of Russian versification (1958-72 only), Akhmadulina, and Brodsky. The Evreinov and Kuprin bibliographies are new; the others were published previously in Russian Literature Triquarterly. Some of the bibliographies include introductory notes, some have indexes, some are in Cyrillic, some are transliterated. Most are complete through 1971. They are all arranged differently: some by year of publication, others by broad categories of publications by and about these authors, and the rest by other arrangements. It is gratifying to see increased interest in bibliography by American literary scholars, but the usefulness of republishing the eight bibliographies is questionable.-RB.

USSR Facts and Figures Annual. 2 vols. Edited by John L. Scherer. Gulf Breeze, Fla.: Academic International Press, 1977-78. Vol. 1: 1977. xii, 320 pp. Vol. 2: 1978 . xv, 559 pp. LC 77-644197.

Based on data drawn both from Western and Soviet sources, this annual statistical handbook presents information on contemporary Soviet life divided topically into fifteen sections. Original sources are footnoted for data presented in tabular form. Statistics for U.S. production levels, military capabilities, and other economic and sociological indicators are provided selectively for purposes of comparison.
Volume 2 is intended for use as a companion to and continuation of volume 1 rather than simply an updated version of the information presented in the first volume. Volume 1 concentrates on the period 1974-76. Volume 2 covers 1977 and contains a survey of the major events of the year in the Soviet Union. Special sections on film and broadcasting, legislation, and municipalities are planned for future volumes.-MS.

\section{Velikaia Oktiabr'skaia sotsialisticheskaia revoliutsiia: Entsiklopediia. Edited by G. N. Golikova and M. I. Kuznetsova. Moscow: "Sovetskaia entsiklopediia," 1977. 712 pp. 6 rubles. LC 78-417035.}

This volume, which updates and greatly enlarges the 1968 encyclopedia of the same title, begins with a general article on the October Revolution and continues with brief entries on personalities, places, and events arranged alphabetically. Nearly every page is illustrated. Entries do not contain bibliographical material, but the volume concludes with a ten-page list of selected scholarly and popular literature, memoirs, belles-lettres, and art on the subject of the October Revolution. Also included are a list of former and current names of cities and a list of abbreviations.-MTC.

\section{UKRAINE AND BELORUSSIA}

Tlumachal'ny sloünik belaruskai movy. Vols. 1 and 2: $A-K . \mathrm{K}$. K. Atrakhovich [Kandrat Krapiva], general editor. Minsk: Haloŭnaia redaktsyia Belaruskai Savetskai Entsyklapedyi, 1977-78. Vol. 1: 604 pp. 5.80 rubles. Vol. 2: 765 pp. 7.30 rubles. LC 78-421649.

Prepared by the staff of the Institute of Linguistics of the BSSR Academy of Sciences, this is the first comprehensive dictionary of the Belorussian language. Some one hundred thousand words are to be included in the projected five-volume work. Because of the emphasis on current usage, many Russian words, particularly scientific and technical terms used in the Soviet Union, are included. The extensive illustrations of use include many 
quotations from Belorussian authors and folk literature. The bibliography of sources from which quotations are taken (nearly all published after the 1940s) and a list of abbreviations are found in the first volume.-DMS.

\section{Ukrainskaia sovetskaia entsiklopediia.}

Vol. 1: A-Borona. M. P. Bazhan, chief editor. Kiev: Glavnaia redaktsiia Ukrainskoi Sovetskoi Entsiklopedii, 1978. 548 pp. 7.50 rubles.

Published in both Ukrainian and Russian editions, this is the second, updated, and abridged edition of the Ukrains'ka radians'ka entsyklopediia, a general encyclopedia published in seventeen volumes (1959-64). The present edition, compiled by the same organization, is scheduled for completion in twelve volumes. The arrangement and content are closer to those of popular Soviet encyclopedic dictionaries than to the first edition or other large Soviet encyclopedias. Technically, with three columns of text and a wide outer margin for illustrations, it resembles an enlarged edition of the three-volume Ukrains'kyi radians'kyi entsyklopedychnyi slovnyk (1966-68).-DMS.

\section{Yugoslavia}

Horton, John J. Yugoslavia. World Bibliographic Series. Oxford: Clio Press, 1977. xvi, 195 pp. \$25.25. LC 78-309357.

The purpose of this selective bibliography on Yogoslavia, according to the compiler, is to "identify those particular contributions, irrespective of length, which appear to be more than usually helpful in illuminating Yugoslav life in its various aspects." The 617 items included are primarily citations to books and articles in English; each entry is annotated in detail. A useful index provides access to citations by author, title, and subject. - HL.

\section{Fast, low cost professional service for}

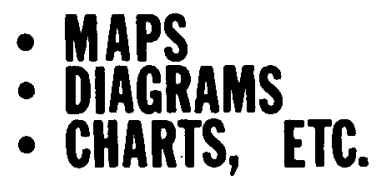

Call or write to:

Ms. ROMANN (201) 646-0007
509 W. Lookout Ave.
Hackensack. N. J. 07601

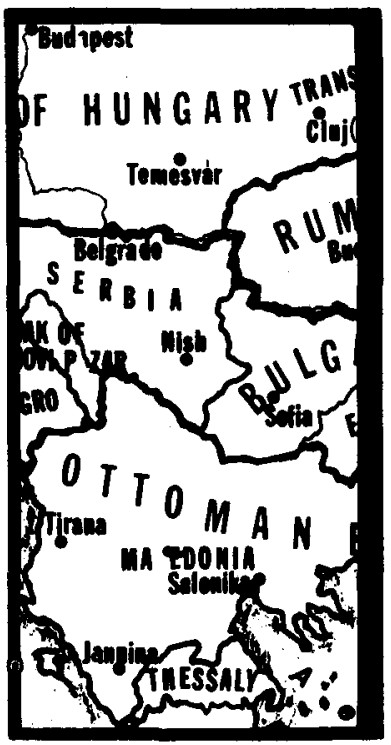

